\title{
Traumás gerincvelősérültek rehabilitációja alsó végtagi humán exoskeletonnal
}

\author{
Tóth Luca dr. ${ }^{1,2,3}$ - Bors Viktória ${ }^{1}$ - Pallag Adrienn ${ }^{1}$ - Pinczker Veronika ${ }^{1}$ \\ Dóczi Tamás dr. ${ }^{1}$. Cserháti Péter dr. ${ }^{4,5}$. Shenker Benjámin ${ }^{4}$ \\ Büki András dr. ${ }^{1}$. Nyitrai Miklós dr. ${ }^{3,6}$ - Maróti Péter dr. ${ }^{3,7}$
}

\author{
${ }^{1}$ Pécsi Tudományegyetem, Általános Orvostudományi Kar, Klinikai Központ, Idegsebészeti Klinika, Pécs \\ ${ }^{2}$ Pécsi Tudományegyetem, Általános Orvostudományi Kar, Transzlációs Medicina Intézet, Pécs \\ ${ }^{3}$ Pécsi Tudományegyetem, 3D Oktatási és Vizualizációs Központ, Pécs \\ ${ }^{4}$ Országos Orvosi Rehabilitációs Intézet, Budapest \\ ${ }^{5}$ Pécsi Tudományegyetem, Általános Orvostudományi Kar, \\ Orvosi Rehabilitáció és Fizikális Medicina Önálló Tanszék, Pécs \\ ${ }^{6}$ Pécsi Tudományegyetem, Általános Orvostudományi Kar, Biofizikai Intézet, Pécs \\ ${ }^{7}$ Pécsi Tudományegyetem, Általános Orvostudományi Kar, Szimulációs Oktatási Központ, Pécs
}

\begin{abstract}
A traumás gerincvelősérültek rehabilitációjában az elmúlt évtizedekben számos technológiai újítás jelent meg, ezek közül kiemelendők az alsó végtagi, aktív robotikus ortézisek, más néven alsó végtagi humán exoskeletonok. A 2000-es évek elejétől számos klinikai kutatás indult meg ezen eszközök hatékonyságának vizsgálatára, bemutatva az exoskeletonok pozitív hatásait a gerincvelő-sérülést követő szövődménybetegségek prevenciójában, illetve progressziójuk lassításában. A korábbi munkák kitérnek a fiziológiai és pszichoszociális, valamint társadalmi hatásokra is, továbbá bemutatják az esetleges kockázatokat, rizikófaktorokat is. Dolgozatunkban kitekintést adunk ezen nemzetközi tanulmányok fontosabb eredményeire, ismertetjük Magyarország első ilyen készülékeinek (ReWalk ${ }^{\mathrm{TM}}$ P6.0) felépítését és múködését, bemutatjuk a robotasszisztált rehabilitációs tevékenység főbb, nemzetközi szinten is használt módozatait, valamint publikáljuk saját, nemzetközi munkákon alapuló vizsgálati protokollunkat, melynek alapján a Pécsi Tudományegyetemen és az Országos Orvosi Rehabilitációs Intézetben multicentrikus kontrollált klinikai vizsgálatot indítottunk. Hipotézisünk, hogy a magas intenzitású, exoskeletonnal kiegészített komplex rehabilitációs tevékenység mind a csontsürüséget tekintve, mind az urogenitalis és gastrointestinalis traktusban pozitív változásokat idéz elö, melyeket objektív urodinámiás és defaecatiós paraméterekkel ellenőrzünk. A csontok ásványianyag-tartalmának változásait DEXA-val mérjük, a mentális statusra gyakorolt hatást kérdőívekkel ellenőrizzük. Kutatómunkánk célja, hogy a paraplegia állapotában lévő felhasználók számára validált eredményekkel alátámasztott, kiegészítő terápiás eljárást dolgozzunk ki, illetve ajánlást adhassunk az otthoni használatra, valamint eredményeinkkel sikerrel csatlakozhassunk a nemzetközi szintû tudományos múhelyek munkájához.
\end{abstract}

Orv Hetil. 2020; 161(29): 1200-1207.

Kulcsszavak: exoskeleton, alsó végtag, rehabilitáció, gerincvelő-sérülés, robotikus terápia

\section{Rehabilitation of traumatic spinal cord injury with lower limb exoskeleton}

In recent years, several technological innovations have emerged to improve the rehabilitation of traumatic spinal cord injury (SCI). Among them, robotic orthosis, also known as human exoskeletons, are prominent devices for lower limb therapy. Since the early 2000 s, numerous clinical studies have begun to investigate the efficacy of these devices, demonstrating the beneficial effects of exoskeletons regarding the prevention and deceleration of the progression of complications following spinal cord injury and subsequent immobilization. Previous works also deal with physiological, psycho-social and social effects, and presents possible risk factors following SCI. In this paper, the main results of the relevant international research is reviewed, the structure and operation of the first devices (ReWalk ${ }^{\mathrm{TM}}$ P6.0) in Hungary are presented, also, the main modalities of robotic assisted rehabilitation activity at international level are demonstrated. Based on the international results, the training protocol for a multicentre controlled clinical trial, involving the University of Pécs and the National Institute for Medical Rehabilitation is presented in this work. Accord- 
ing to our hypothesis, high intensity exoskeleton-assisted complex rehabilitation induces positive changes in bone density, in the urogenital and gastrointestinal tract. Changes are quantified by objective urodynamic and defecative parameters. The difference in bone density is assessed with DEXA scan, and the effects on mental status are evaluated by questionnaires. The aim of this research is to promote a complementary therapeutic procedure based on validated results for SCI patients with paraplegia, also to establish recommendations for home use of the robotic exoskeletons, and to conceivably join to international scientific research projects.

Keywords: exoskeleton, lower extremity, rehabilitation, spinal cord injury, robotics

Tóth L, Bors V, Pallag A, Pinczker V, Dóczi T, Cserháti P, Shenker B, Büki A, Nyitrai M, Maróti P. [Rehabilitation of traumatic spinal cord injury with lower limb exoskeleton]. Orv Hetil. 2020; 161(29): 1200-1207.

(Beérkezett: 2020. március 4.; elfogadva: 2020. április 6.)

\section{Rövidítések}

$6 \mathrm{MWT}=(6$-minute walk test $) 6$ perces járásteszt; $10 \mathrm{mWT}=$ (10-meter walk test) 10 méteres járásteszt; AIS = (ASIA Impairment Scale) ASIA által kidolgozott skála; AoDL = (activities of daily living) napi aktivitási szint; ASIA = (American Spinal Injury Association) Amerikai Gerincsérülés Egyesület; BWS = (body-weight support) a test tehermentesítése; DEXA = (dual energy X-ray absorptiometry) kettős energiájú röntgensugárelnyelődés mérése; DOF $=($ degree of freedom $)$ szabadságfok; FDA $=$ (U.S. Food and Drug Administration) az Amerikai Egyesült Államok Élelmiszer-biztonsági és Gyógyszerészeti Hivatala; FES = funkcionális elektromos stimuláció; GINOP = Gazdaságfejlesztési és Innovációs Operatív Program; MET = a fizikai aktivitás metabolikus egysége, a mozgás számszerúsítésére használt egység; OGYÉI = Országos Gyógyszerészeti és Élelmezés-egészségügyi Intézet; OTKA = Országos Tudományos Kutatási Alapprogramok; SCI $=$ (spinal cord injury $)$ gerincvelö-sérülés; tDCS = (transcranial direct current stimulation) transcranialis direktáram-stimuláció; TENS = (transcutaneous electrical nerve stimulation) transzkután elektromos idegstimuláció; TMS = (transcranial magnetic stimulation $)$ transcranialis mágneses stimuláció; TUG $=($ timed up and go $)$ a felálláshoz és elinduláshoz szükséges idő; USA = (United States of America) Amerikai Egyesült Államok

A traumás gerincvelő-sérülések hazai és nemzetközi viszonylatban egyaránt az aktív korú népességet érintik a leginkább; okaik elsősorban közúti, közlekedési balesetek $[1,2]$. Az állapot prevalenciája az Egyesült Államokban 39/1 000000 fó, Ausztráliában 16/1 000000 fó, míg Nyugat-Európában 15/1 000000 fó. Hazánkban az esetszám az Egyesült Államok és Nyugat-Európa prevalenciaértékei közé tehető. Elsősorban férfiakat érint $(79,8 \%)$ [3], és a korosztályt illetően bimodális eloszlás jellemző: az egyik csúcs 15-29 év között, míg a másik - kisebb emelkedéssel - az 50 év feletti korosztályban található $[4,5]$. A kimenetel tekintetében rendkívül fontos a sérülés szintje, az esetek több mint fele (körülbelül $60 \%$ ) cervicalis, $32 \%$ thoracalis és $9 \%$ lumbosacralis laesio [3]. A sérülés szintjétôl és a gerincvelö-károsodás kiterjedésétől függően kialakulhat para- vagy tetraparesis, illetve para- vagy tetraplegia [2]. A betegek életminőségének súlyos csökkenése mellett a szekunder betegségek, komplikációk kialakulása várható az immobilizáció miatt: osteoporosis, 2-es típusú diabetes mellitus, decubitus, patológiás fraktúrák, obesitas, izomatrophia, dyslipidaemia és atherosclerosis [6-8]. A tragikus hirtelenséggel megváltozott életkörülmények miatt a gerincvelősérült betegeknek hozzávetőlegesen a $20-45 \%$-a szenved depressziótól, ennek következtében a suicidium előfordulása közöttük többszörös az azonos életkorú, nem sérült személyekhez képest [9]. Egy amerikai tanulmány szerint az egy betegre fordított egészségügyi kiadások nagysága annak egész élete folyamán elérheti a 1,1-1,46 millió USD körüli összeget [10], ezért kiemelten fontos szereppel bír a szövődmények kialakulásának megelőzése, valamint a mielőbb társadalmi reintegráció.

A prognózist és a rehabilitációs célt tekintve a sérülés kiterjedése és lokalizációja a legfóbb meghatározó tényező [11]. A gerincvelő-sérülés kiterjedésének meghatározására nemzetközileg elfogadott az ASIA (American Spinal Injury Association) által kidolgozott skála (ASIA Impairment Scale, AIS) (1. táblázat) [12, 13]. A kimenetelt tekintve a legjelentôsebb neurológiai javulás $(95,2 \%)$ az AIS szerinti $\mathrm{D}$ sérülés esetén várható, míg ugyanennek az esélye az AIS szerinti A sérülést követően lényegesen kisebb $(7,7 \%)$, aktív kezelést követően is [11]. A gerincvelő-laesio szintje is jelentősen befolyásolja a kimenetelt: a neurológiai javulást tekintve a legroszszabb a prognózis a thoracalis sérülés esetén, míg a legjobb kimenetel a lumbalis sérülést követően várható [11, 12]. A sérülést követően elérhető javulás és regeneráció mértékét meghatározza továbbá a beteg egészségi állapota, esetleges komorbiditás jelenléte, az egyéni motiváció és az ezzel szorosan összefüggő, magas szintű rehabilitációs ellátás $[12,14]$.

A rehabilitációs tevékenység támogatására, kiegészítésére több új eljárás, segédeszköz, megoldás született az elmúlt évtizedekben. A gyógytornászok és rehabilitációs szakorvosok munkáját számos technológiai vívmány segítheti napjainkban; ezek között előkelő helyen szerepelnek a különböző, robotasszisztált terápiás eljárások, melyek mind a felső, mind az alsó végtag esetén jelentôsen javíthatják a felhasználó funkcionális állapotát és napi aktivitási szintjét (activities of daily living - AoDL) stroke 


\begin{tabular}{l|ll} 
1. táblázat & Az AIS-beosztás & \\
\hline AIS-beosztás & Tünet & Laesio \\
\hline A & $\begin{array}{l}\text { Teljes érzés- és mozgáskiesés, } \\
\text { az S4-S5 szegmentumra kiterjedően is }\end{array}$ & Komplett \\
\hline B & $\begin{array}{l}\text { Az alap neurológiai szint alatt } \\
\text { akaratlagos izommozgás nincs, az } \\
\text { S4-S5 szegmentumban az érzőfunkci- } \\
\text { ók megtartottak }\end{array}$ & Inkomplett \\
& $\begin{array}{l}\text { Az alap neurológiai szint alatt a } \\
\text { motoros akaratlagos mozgások } \\
\text { megtartottak, de a kulcsizmok } \\
\text { minimum 50\%-a esetén az izomerố } \\
\text { kevesebb, mint 3 }\end{array}$ & Inkomplett \\
\hline C & $\begin{array}{l}\text { Az alap neurológiai szint alatt a } \\
\text { motoros akaratlagos mozgások } \\
\text { megtartottak, de a kulcsizmok } \\
\text { minimum 50\%-a esetén az izomeró } \\
\text { minimum 3 }\end{array}$ & Inkomplett \\
\hline D & $\begin{array}{l}\text { Motoros vagy szenzoros eltérés nem } \\
\text { található }\end{array}$ & Normál \\
&
\end{tabular}

AIS = az ASIA által kidolgozott skála; ASIA = Amerikai Gerincsérülés Egyesület

$[15,16]$ vagy gerincvelö-sérülés után $[13,17]$. A robotikus terápia előnye, hogy lehetőséget teremt személyre szabott, célorientált funkcionális, intenzív gyakorlatok elvégzésére, magas ismétlésszámban, mialatt a mozgásterapeuták terhelése redukálódhat, valamint a kezelési költségek csökkenhetnek [17]. A repetitív, feladatorientált gyakorlatok a fokozott sensomotoros aktivitás kiváltásával és az adaptív plasticitas serkentésén keresztül [18] kiemelt jelentőséggel bírnak a funkcionalitás javításában a gerincvelősérülttek rehabilitációja során [13, 17]. Korábbi kutatások bizonyították, hogy ezek az új eszközök az inaktív életmód szövődményeként kialakuló társbetegségek valószínúségét is képesek csökkenteni $[8,17$, 18]. Ez a megállapítás alapvető fontosságú, hiszen a napi aktivitási szint növelésével az életminőség (quality of life) és a társadalomba való visszailleszkedés esélye is nagymértékben javulhat $[13,19]$.

Az utóbbi évek során számos robotikus eszköz került egészségügyi, terápiás használatba, ezeket többféleképpen csoportosíthatjuk. A témában a hazai, kitekintő jellegú vizsgálatok megkezdődtek, elsősorban a felső végtagi alkalmazásokat illetóen $[20,21]$, az alsó végtagra fókuszáló munka azonban ez idáig még nem kezdődött meg. Az alsó végtagi robotikus eszközök általánosan két típusba sorolhatók: a robotikus külső ortézis (exoskeleton) és a végberendezés (end effector) (1. ábra).

A végeffektorrendszer a végtag legdistalisabb pontját mozgatja a tér bármely irányában, egy csatlakozási ponton keresztül, ami alsó végtag esetén egy lábtámasz (footplate-based) vagy mobilis platform (platformbased) segítségével történik, így nincs szükség a beteg méretarányai szerint igazítani a robot méreteinek beállítását (1. ábra) [17, 22, 23]. Az exoskeletonok felépítése során a végtag anatómiai és biomechanikai tulajdonságai

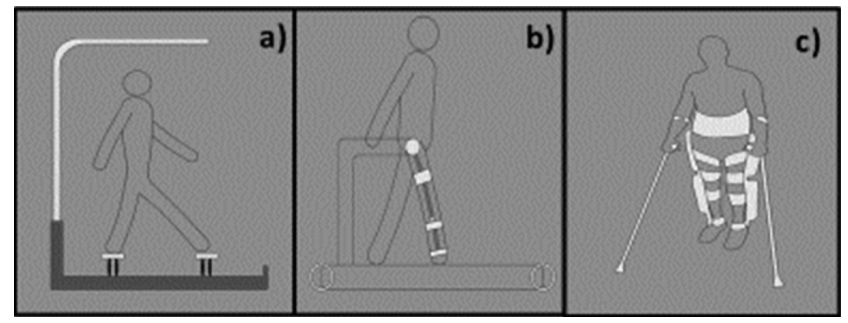

\begin{tabular}{l|l} 
1. ábra & Különböző típusú alsó végtagi robotikus rendszerek sematikus
\end{tabular} ábrázolása. a) Végeffektorrendszer, b) futópad alapú exoskeleton, c) szabadon álló exoskeleton

alapján készül el a robotikus ortézis, így az aktuátorok minden ízületet előre programozott mozgástartományban képesek mobilizálni, ezzel az élettani mozgásmintát szimulálni $[20,23,24]$. Az exoskeletonok további csoportosítása lehetséges az aktívan vezérelt ízületek száma szerint (degree of freedom - DOF), illetve uni- és bilateralis kialakítás alapján $[20,22]$. A rehabilitációs célt tekintve elkülöníthetjük a terápiás robotokat, melyek célja a mozgástartomány és a funkcionalitás növelése neurológiai károsodást követően klinikai körülmények között. Alsó végtag esetén asszisztív robotokról beszélünk, amennyiben olyan személy használja a robotot - döntốen mindennapi életkörülmények között -, akinek állapota az orvostudomány jelenlegi állása szerint végleges, és a hagyományos eszközökkel szemben (például kerekes szék) a robot nagyobb életteret, önállóságot és funkcionalitást, illetve közösségben történő használatot biztosít. Emellett kiemelendő az asszisztív robotok által elérhető aktív életvitel pozitív hatása a potenciális komplikációk megelőzésében. A rehabilitációs elv szerint az exoskeletonok tovább osztályozhatók „statikus”, azaz futópad alapú (treadmill-based) eszközökre, például Lokomat ${ }^{\circledR}$ (Hocoma, Inc., Norwell, MA, USA), és szabadon álló ortézisekre, például ReWalk ${ }^{\mathrm{TM}}$ (ReWalk Robotics, Inc., Marlborough, MA, USA) (1. ábra) [22, 24]. A futópad alapú rendszerek segítségével lehetôség nyílik a terápia során felfüggesztést alkalmazni, ezzel személyre szabott mértékben lehetséges a tehermentesítés (body-weight support - BWS), hátrányuk viszont, hogy az eszközök mobilizálása azok mérete és komplexitása miatt nem vagy csak nehézkesen kivitelezhető, így csak terápiás felhasználásuk lehetséges $[17,22]$. A szabadon álló ortézisek használatához rendszerint ép felső végtagi funkció és segédeszköz (rollátor vagy könyökmankó) használata szükséges a megfelelő egyensúly megtartásához, így robottípustól függően lehetővé teszik mind a terápiás-klinikai felhasználást, mind pedig az otthoni, asszisztív ellátásban történő alkalmazást (2. ábra) $[17,22]$.

A robotikus eszközök a múködésüket tekintve lehetnek aktív, passzív, kisegítő aktív, ellenállással szembeni és interaktív készülékek $[20,22]$. Az aktív mód során a felhasználó aktív támogatást kap a mozgás kivitelezésére; a passzív múködés mechanikus támasztást biztosít a lépés során, míg a kisegítő aktív eszköz a mozgás indítását követően a szükséges mértékben pótolja és biztosítja a 


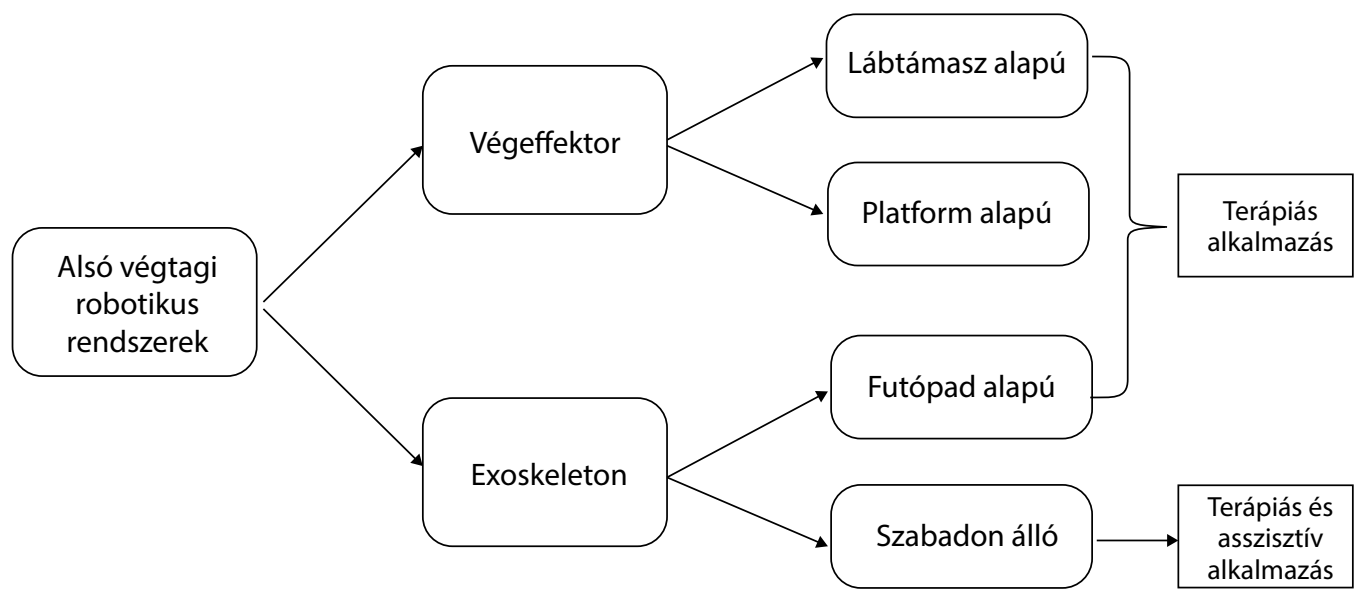

2. ábra

| Az alsó végtagi robotikus rendszerek különböző típusai

megkezdett mozgás kivitelezését. Az ellenállással szembeni üzemmód személyre szabott érték alapján a mozgással ellentétes irányú rezisztenciát biztosít a tréning során; a kisegítő aktív eszköz képes előre beállított paraméterek alapján a megkezdett mozgás korrigálására és a helyes kivitelezés segítésére. Számos robotikus eszköz alkalmas a mozgástámogatást személyre szabott mértékben asszisztálni („assist as need mode”), ennek során a terapeuta a teljes robotikus támogatástól (100\%) a beteg állapota szerint tudja megválasztani a robot által biztosított mozgástámogatást, ami lehetőséget teremt a rehabilitáció elején a fizikailag gyengébb személyeken történő alkalmazásra is.

Összefoglaló tanulmányunk a továbbiakban a robotikus „statikus” exoskeletonok egészségügyi vizsgálatával foglalkozik.

Bár számos kísérleti eszköz létezik, melyek célja kisebb csoportokon végzett, lokális vizsgálatok elvégzése, FDA(Food and Drug Administration) minősítéssel jelenleg mindösszesen három típus rendelkezik [17]: a ReWalk ${ }^{\mathrm{TM}}$ [http://rewalk.com/], az Ekso® (Ekso Bionics, Richmond, CA, USA) [https://eksobionics.com/] és az Indego $^{\text {TM }}$ (Parker Hannifin Corp., Cleveland, OH, USA) [http://www.indego.com/indego/en/home]. Az eszközök közül az Indego ${ }^{\mathrm{TM}}$ és a ReWalk ${ }^{\mathrm{TM}}$ rendszer alkalmas asszisztív, otthoni használatra, míg az Ekso® kizárólag egészségügyi intézményekben, szakember felügyelete mellett használható terápiás céllal.

\section{Összefoglaló a nemzetközi vizsgálatok eredményeiről}

A robotikus terápia egészségügyi térhódítása a 2000-es évek elején kezdődött, ezért nagy volumenű utánkövetéses vizsgálatokra eddig nem volt lehetőség - így az öszszegzés során fontos szempont, hogy a legtöbb vizsgálat kis elemszámú kutatás eredményét ismerteti, valamint a vizsgált csoportok és az alkalmazott tréningprotokollok heterogenitása igen magas.
Számos tanulmány vizsgálta a robotikus terápia klinikai biztonságosságát és a terápia következtében kialakuló lehetséges szövődményeket. A technológia biztonságosságát az esések, a bőr állapota (esetleges fekélyek kialakulása), az ízületek és a gerinc stabilitása, valamint a vitális paraméterekben kialakuló változások alapján tanulmányozták $[17,25,26]$. Az eredmények alapján kimondható, hogy a robotikus terápia biztonságos, a vizsgálatok során komoly szövődmények nem jelentkeztek, fontos viszont kiemelni, hogy e komplikációk megelőzése érdekében a felhasználás során különös figyelmet kell fordítani a szoftveres beállítások többszörös ellenőrzésére, illetve a felső végtaggal és segédeszközzel megvalósítandó egyensúly biztosítására.

A felső motoneuron-laesiót követően gyakori szövődmény a spasticitas és a krónikus neuropátiás fájdalom, mely a betegek életminőségét jelentősen rontja [13, 17]. A robotikus terápia pozitív hatással van a spasticitas csökkentésére. Mind rövid távú kezelést követően (megközelítően 40 perc), mind hosszabb távú vizsgálatok során bizonyítottan javult a spasticitas mértéke, a módosított Ashworth-skálán és a szubjektív percepciót vizsgálva is [17, 27-29]. A krónikus fájdalom csökkenésének irányában történő vizsgálatok szintén biztató eredménnyel zárultak [22, 27-29].

A krónikus gerincvelő-sérülést követően a szív- és érrendszeri szövődmények a korai mortalitás egyik legfontosabb okai $[7,17]$. Az inaktív életmód miatt fokozott a kockázata a major cardiovascularis rizikófaktorok (obesitas, lipidanyagcsere-zavar, metabolikus szindróma és diabetes mellitus) kialakulásának $[6,8]$. A laesio miatt kialakuló autonóm diszfunkció következtében fokozott a magas vérnyomás, az arrhythmia kialakulásának veszélye, és csökken a cardiovascularis rezervkapacitás, ami hozzájárul a komplikációk nagymértékü kialakulásához [8]. Az aktív, robotikus terápia következtében a szív- és érrendszerben kimutatható változások vizsgálatára számos kutatás irányult $[17,25,30]$. Robotasszisztált járástréning során az oxigénfelhasználás, valamint a szívfrekvencia fokozódik [30]; a fizikai aktivitás metabolikus 
egységben (MET) kifejezve átlagosan 3,3 [25], mely megfelel egy egészséges ember által végzett átlagos testmozgásnak, és bizonyított a preventív hatása a mortalitást tekintve $[17,25,30]$. Az inaktív életmód következtében kialakuló kóros testösszetételre is pozitív hatásai vannak az aktív robotikus tréningnek: bizonyítottan csökken a zsírszövet tömege, és nő az izomszövet, különösen az alsó végtagokon $[17,22,25]$. Az eredmények alapján feltételezhető, hogy a robotikus terápia pozitív hatással van a szív- és érrendszeri komplikációk csökkentésére, rendkívül fontos azonban, hogy az eszköz milyen üzemmódban múködik, tekintettel arra, hogy a passzív mód lényegesen kisebb aktív energiafelhasználást igényel, mint az aktív vagy aktív-asszisztált tréning.

Az elmúlt évek kutatásai egyértelmúen bizonyítják, hogy az exoskeletonnal elérhető járástréning során az ambuláns funkciókat tekintve jobb eredmények érhetők el az olyan tradicionális segédeszközökkel szemben, mint a körsínes ortézis [22, 28]. Általánosan elmondható, hogy a betegek el tudták sajátítani a robot használatához szükséges elméleti és gyakorlati készségeket, átlagosan 8 hét alatt már szignifikánsan csökkent a gép önálló felvételéhez szükséges idő [28]. A járásfunkcióban elérhető javulás függ a laesio kiterjedésétől (komplett vagy inkomplett) és az alkalmazott tréningprotokolltól is. Összességében elmondható, hogy a gyakorlatban használt mérőskálákkal - például 10 méteres járásteszt (10mWT), 6 perces járásteszt (6MWT), felálláshoz és elinduláshoz szükséges idő (TUG) - a sebesség, az állóképesség terén kimutatható változás lényegesen jobb a robotikus terápia esetén, mint a konvencionális terápiát követően [17, 22, 25-27, 29]. A robotikus rendszerekkel elérhető változás miatt a krónikus gerincvelősérült betegek funkcionalitása, függetlensége és életminősége javul, ami fontos szempont a társadalomba történő reintegrációhoz, illetve a pszichológiai szövődmények megelőzéséhez [17, 25, 27-29].

A krónikus gerincvelő-sérülést követően kialakuló öszszetett hormonális változások és az inaktív, ülő életmód következtében a betegek jelentős arányában csökken az alsó végtagok terhelése, és fokozódik a csontreszorpció, ezzel a csontritkulás és ennek talaján a patológiás fraktúrák kialakulása gyakoribb $[6,7,17]$. Az exoskeletonnal végzett rendszeres járás és állás ezeket a folyamatokat kedvezően befolyásolhatja, különösen a csontdenzitást illetően $[17,25]$.

A gerincvelö-sérülés okozta vegetatív diszfunkciók gyakran érintik az urogenitalis és a gastrointestinalis traktust, ezzel jelentősen befolyásolva az életminőséget. $\mathrm{Az}$ álló testhelyzet, illetve a testmozgás következtében már rövid távú terápiát követően is pozitív változásokat jeleztek a kutatásban részt vevők a defaecatiós idő és az enema csökkenésére vonatkozóan, illetve a felhasználók körében a tréning alatt és az azt követő 30 percben fokozott és szabályosabb bélmozgásokról számoltak be [17, $25,28]$.
A thoracalis gerincvelősérült, alsó végtagi érintettség miatt kerekes széket használó páciensek esetében a szociális és a munkahelyi reintegráció egyik fó akadályát az épített és a természetes környezetben fellelhető fizikai akadályok jelentik [31]. Ezek leküzdésére viszonylag új módszernek tekinthetők az asszisztív, otthoni alkalmazásra alkalmas robotok. Az exoskeletonok asszisztív, közösségben történő felhasználására vonatkozó kutatások főként a járás sebességét vizsgálták, és megállapították, hogy az otthoni használatra engedélyezett robotokkal megfelelő felkészítést követően a komplett gerincvelősérült betegek a mindennapi környezetben sikeresen tudnak helytállni, ami részben az álló testhelyzettel kivitelezhető magasabb funkcionalitásnak köszönhető [22, 25 ].

Az elmúlt évek robotikus kutatásainak egyik központi és rendkívül ígéretes iránya a rehabilitációs kezelés moduláris, noninvazív eszközökkel történő bővítése. A sérülés típusától és kiterjedésétől függően a laesio szintjétől distalisan a spinalis neuronok összeköttetése részben vagy teljesen megszakad a supraspinalis központokkal, ennek következménye a neurológiai funkcióvesztés. A robotikus gerincvelő-sérülés rehabilitációja során alkalmazott moduláris eszközök az idegrendszer stimulálásával serkentik a cerebralis és spinalis plasticitast, ezáltal potencírozzák a neurológiai javulást [12, 32-34].

Ezen eszközök két fó csoportra oszthatók: a noninvazív transcranialis stimuláló eszközök, illetve a perifériás, felszíni stimulátorok csoportjára. Az előbbi csoporthoz tartozik a transcranialis mágneses stimuláció (TMS) és a transcranialis direktáram-stimuláció (tDCS), melyek alkalmazásával biztató eredmények érhetők el a spasticitas és a neuropátiás fájdalom csökkentésében, valamint - feltehetően a permanens neuromoduláció következtében a funkcionalitás fejlesztésében is [17, 32].

A felszíni stimulátorok közül a neurorehabilitáció területén kiemelendő a transzkután elektromos idegstimuláció (TENS), valamint a funkcionális elektromos stimuláció (FES), mely kiegészítő terápiaként, illetve a robotikus tréning során alkalmazott eljárásként is megjelenhet [18, 32-35]. Korábbi kutatások alapján a FESterápiával bóvített neurorehabilitáció során magasabb funkcionalitás és kedvezőbb eredmények érhetők el a spasticitas, a neuropátiás fájdalom, az izomatrophia, valamint a fáradtság csökkentésében, illetve a gastrointestinalis és az urogenitalis traktusnak a vegetatív diszfunkciók következtében kialakuló zavaraiban [32-35].

Mindemellett számos olyan fejlesztési projekt indult, melyben a moduláris stimuláló eszközök a robotok részeként jelennek meg, ezzel komplex ember-gép rendszereket hozva létre, $s$ tovább potencírozva a neurorehabilitáció sikerességét [32]. Az ember-gép rendszerek tervezésekor különösen fontos, és figyelmet igényel, hogy a robotikus mozgás ergonomikus, természetes járásmintát biztosítson, valamint folyamatos összhangban legyen a humánkapacitással, illetve adaptív kontroller segítségével a felhasználó számára adaptált és egyedi vezér- 
lést biztosítson, ezzel hozzájárulva a neurorehabilitáció sikerességének növeléséhez és a robotok otthoni felhasználásának szélesebb körü elterjedéséhez [36].

A robotikus eszközök további előnyei közé tartozik, hogy a beteg számára interaktív, a konvencionális terápiához képest izgalmasabb, személyre szabott a tréning, továbbá lehetőséget teremt virtuálisvalóság- vagy augmentáltvalóság-eszközökkel történő kiegészítésre, ami igen jó hatással van a motiváció fenntartására. A legtöbb esetben az eszközbe épített goniométer segítségével a terápia során elért változások könnyedén kvantifikálhatók, így akár mozgásanalizáló rendszer használata nélkül is pontos képet kapunk az érintett végtagok mozgástartományában bekövetkező fejlődésről, aminek segítségével a terápia követhető és az egyéni fejlődés szerint személyre szabható.

A nemzetközi szakirodalom rávilágít e rendszerek előnyeire, ám az is kiemelendő, hogy az eredmények megerősítésére szélesebb körü klinikai vizsgálatok elvégzése szükséges [17, 18]. A vizsgálatok heterogenitására való tekintettel számos szakmai kérdés tisztázatlan ez idáig, így például a technológiából legtöbbet profitáló betegcsoport definiálása, a várt egészségnyereséghez és a komplikációk elkerüléséhez szükséges tréningprotokoll minimumkövetelményei, különös tekintettel a tréning idejére.

Kutatócsoportunk célja, hogy Magyarországon elsőként csatlakozzon ezen a tudományterületen a nemzetközi vizsgálatokhoz, a Pécsi Tudományegyetem Klinikai Központ Idegsebészeti Klinikája és az Országos Orvosi Rehabilitációs Intézet szoros együttmúködésében. A jelen közleményben célunk az országban elsőként telepített ReWalk ${ }^{\mathrm{TM}}$ P6.0 humán alsó végtagi exoskeleton bemutatása, a nemzetközi standardokon alapuló hazai vizsgálati protokoll disszeminációja, valamint a technológia lehetőségeinek részletesebb megismertetése a rehabilitációs területen dolgozó szakemberekkel.

\section{Jövőbeli direktívák, módszer}

Kutatásunk során ReWalk ${ }^{\mathrm{TM}}$ P6.0 exoskeletont használunk, mely mind klinikai, mind otthoni használatra engedélyezett. Az exoskeleton két aktív ízülettel (csípó és térd), illetve egy mechanikus bokaízülettel rendelkezik. A további múszaki paraméterek összegzése a 2. táblázatban található.

A robot ergonomikus kialakításának köszönhetően teljesen önhordó, ezért használat közben a súlyával nem terheli a felhasználót. Az exoskeleton teljesen önjáró, viszont a múködtetéshez elengedhetetlen az ép felső végtagi funkció és a könyökmankó használata. A ReWalk ${ }^{\mathrm{TM}}$ lehetőséget teremt arra, hogy megfelelő gyakorlást követően a felhasználó maga irányítsa az eszközt egy hozzá tartozó okosóra segítségével. A készülék személyre szabható a különböző méretű, cserélhető medenceövek és talprészek segítségével, illetve a distalis váz a femur és a tibia hosszúságának megfelelően könnyedén beállítható.
2. táblázat |A ReWalk ${ }^{\mathrm{TM}}$ P6.0 főbb műszaki jellemzői

\begin{tabular}{ll}
\hline A felhasználó maximális tömege & $100 \mathrm{~kg}$ \\
A felhasználó testmagassága & $160-190 \mathrm{~cm}$ \\
A medenceszalag szélessége & $29-37 \mathrm{~cm}(2 \mathrm{~cm}$-ként növelhető $)$ \\
A rendszer teljes tömege & $30 \mathrm{~kg}$ \\
A járás maximális sebessége & $2,3 \mathrm{~km} / \mathrm{h}$ \\
A csípő mozgástartománya & $34^{\circ}$ extenzió, $104^{\circ}$ flexió \\
A térd mozgástartománya & $110^{\circ}$ flexió, $2^{\circ}$ extenzió \\
Üzemidő & $\begin{array}{l}\text { Minimum } 3 \text { óra, tartalék } \\
\text { akkumulátor + } 15 \text { perc }\end{array}$ \\
\hline
\end{tabular}

A felhasználó csatokkal rögzíthető, párnázott hevederekkel biztosíthatja magát az exoskeletonban (3. ábra).

A robot képes aktív módon segíteni a felhasználónak a felállás és a leülés kivitelezésében, a járásban, illetve a lépcsőzésben is. Az eszközhöz tartozó szoftver segítségével előre, egyénre szabottan beállíthatók a járás paraméterei, így a lépésidő $(\mathrm{m} / \mathrm{s})$, a két lépés közötti szünet ideje, a csípő- és a térdflexió mértéke. Az okosórán a megfelelő

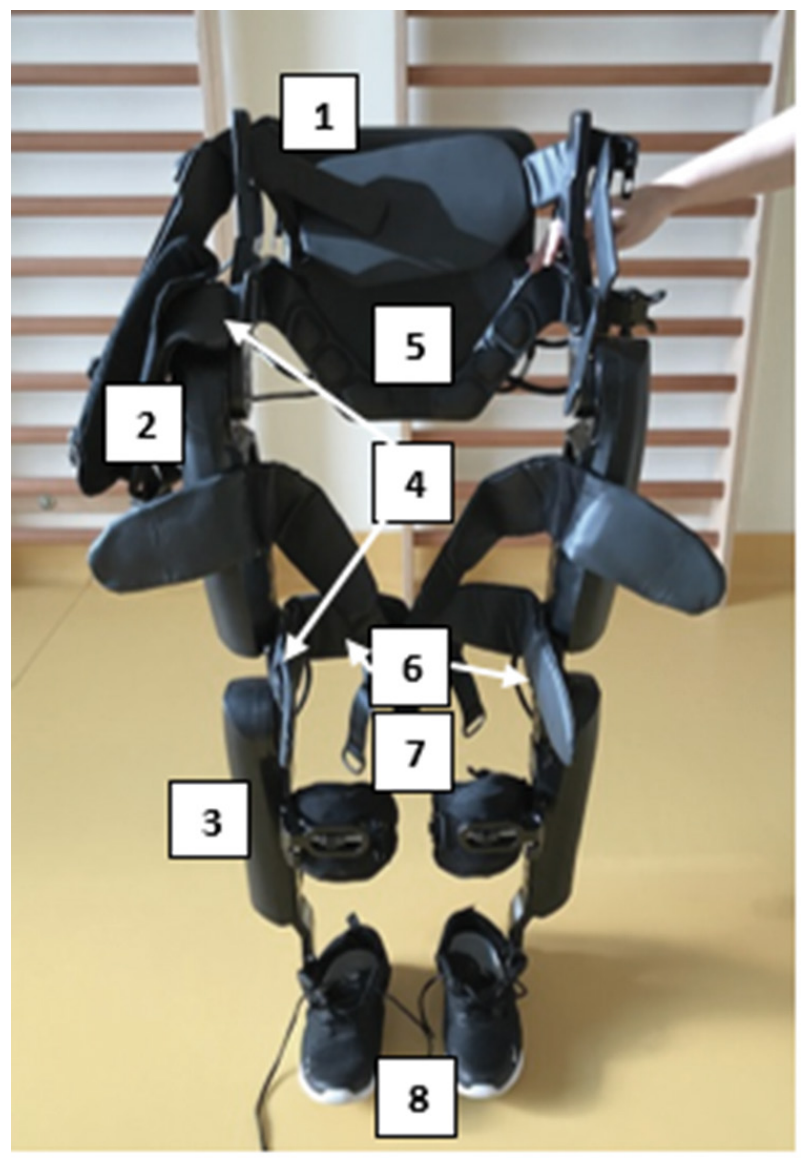

3. ábra

A ReWalk ${ }^{\mathrm{TM}}$ P6.0 felépítése elölnézetből. 1) „Derékcsomag” elektronikai komponensek tárolása és támasztófunkció. 2) Proximalis vázegység, külső burkolattal, jobb oldal. 3) Distalis vázegység, külső burkolattal, jobb oldal. 4) Aktuátorok, melyek a mozgatásért felelősek, jobb oldal. 5) Háti rész, párnával és hevederekkel. 6) Comb- és térdhevederek. 7) Térdet támasztó merev vázelem. 8) Lábtámasz, cipővel 


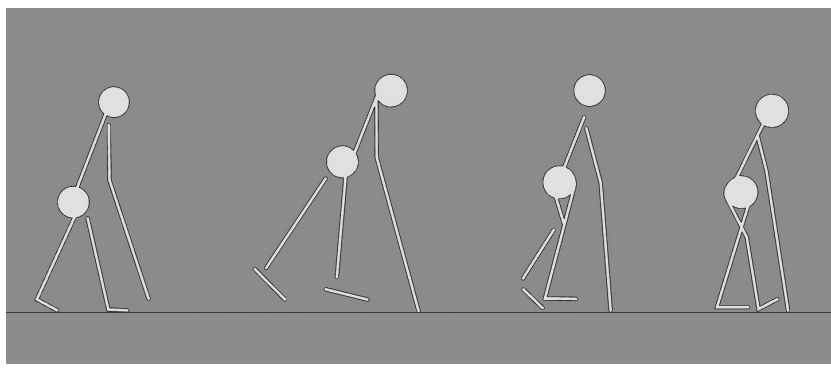

4. ábra

| Az exoskeletonnal történő járás sematikus ábrázolása

mód kiválasztása után a robot hangjelzést ad. Ezt követően a felhasználónak kell a mozgást egy csípólendítéssel iniciálni, melyet egy szenzor érzékel, és ezt követően indul az előre beprogramozott járásminta (csípő- és térdflexió, majd extenzió), így jön létre egy lépés (4. ábra). A felhasználás során minden lépést aktívan kell a betegnek súlypontáthelyezéssel indítani; amennyiben ez nem történik meg, biztonsági okból a program kiválasztásának ellenére sem indít mozgást a robot.

Kutatásunk során célul tûztük ki, hogy egy magas intenzitású, robotikus járástréning hosszú távú hatásait vizsgáljuk a konvencionális terápiához képest, komplett (AIS szerinti A) gerincvelősérült betegeken. A vizsgálati protokollt nemzetközi adatok alapján állítottuk össze. [17, 18, 25-28]. A multicentrikus vizsgálatot a Tudományos Kutatásetikai Bizottság az OGYÉI/1271-2/2020 számmal engedélyezte. A vizsgálatba olyan, 18. életévüket betöltött betegeket vonunk be, akik tájékoztatást követően írásban beleegyeztek a kutatásban való részvételbe, és thoracalis IV. csigolyaszint alatti komplett sérülést szenvedtek a bevonást megelőzően minimum 4 hónappal, továbbá az aktív tréninghez megfelelő csontsűrûséggel és alsó végtagi passzív mozgástartománnyal rendelkeznek.

A robotikus tréning négy fázisra osztható. Az első fázisban személyre szabott felkészítő gyógytorna történik, mely a robot irányításához és biztonságos használatához megfelelő ülőegyensúly, a dinamikus törzsegyensúly és a felső végtagi erőnlét kialakítását szolgálja. Az elért változást a törzskontrollteszttel ellenőrizzük. A második fázisban a beteg elsajátítja a gép önálló felvételét, majd a felállás és a leülés technikáját. Ezen szakaszban külön figyelmet kap az álló helyzetben történő egyensúly fejlesztése, valamint a két, illetve egy mankóval történő állás és manőverezés kivitelezése. A változásokat a törzskontrollteszttel és a Berg-féle balance-teszttel értékeljük. A harmadik fázisban a beteg elsajátítja az önálló járás képességét a robot segítségével. A járás képességét és a mindennapi akadályok leküzdésének sikerességét ügyességi tesztekkel értékeljük. Az első három fázis során heti 5 alkalommal, alkalmanként 60-90 percig tart a tréning. Ezt követően egy alacsonyabb intenzitású, fenntartó járásterápia következik 6 hónapon keresztül, heti 3 alkalommal. A kontrollcsoport ugyanilyen intenzitású, de konvencionális fizioterápiában részesül.

\section{Megbeszélés}

Hipotézisünk szerint a magas intenzitású, aktív tréning segítségével megelőzhetők, illetve csökkenthetők a gerincvelő-sérülés következtében kialakuló, inaktív életmódból fakadó, hosszú távú szövődmények. Kutatásunk során nagy hangsúlyt kap a testösszetétel és a csontsűrüség vizsgálata, mely az egyik leggyakoribb szövődménye az inaktív életmódnak. Az aktív, robotikus terápia hatásai közé tartoznak a gastrointestinalis és az urogenitalis traktusban kimutatható pozitív változások, melyeket urodinámiás vizsgálatokkal, valamint defaecatiós paraméterekkel ellenőrzünk. A tréningnek kiemelt jelentósége van a mentális statusban, illetve az életminőségben bekövetkező változások tekintetében, ezeket validált kérdőívekkel követjük. Az exoskeleton használata során lehetőség nyílik a paraplegiában szenvedő gerincvelősérülteknek az aktív járás megvalósítására és a független, szabad életmód megalapozására. Ezen kimeneteleket mérföldkövenként tesztek segítségével objektivizáljuk, és az elért változásokat azonos állapotú, de konvencionális gyógytornában részesülő betegekhez hasonlítjuk. A kutatást két évig tervezzük folytatni. Célkitűzésünk, hogy a vizsgálattal bizonyítsuk az aktív, exoskeletonnal végzett járásterápia nagymértékü hatékonyságát, s ezzel hozzájáruljunk a technológia szélesebb kutatási és betegellátási körben történő elterjedéséhez. A ReWalk ${ }^{\mathrm{TM}}$ P6.0 exoskeleton-rendszerből világszerte megközelítőleg ötszáz rendszer található klinikai és otthoni használatban, ezzel biztosítva a betegek mindennapi funkcionalitásának növelését is. Jövőbeli hazai elterjedésének elősegítésével összhangban célszerü lehet az eszköz finanszírozása során megvizsgálni a potenciális egyéni vagy rendszerszintű támogatási lehetőségeket.

Anyagi támogatás: A kutatásunk során használt eszközök a GINOP-2.3.3-15-2016-00032. sz. „Neurorehabilitáció és Ember-Gép Kapcsolat Kutatási Központ” címú pályázat támogatásából kerültek beszerzésre, a vizsgálat a Pécsi Tudományegyetem „Tématerületi Kiválósági Program 2019 - Biomedical Engineering Projekt” keretén belül valósul meg (TUDFO/51757-1/2019ITM). A „Tématerületi Kiválósági Program 2019” pályázatban T. L., Ny. M., B. V., P. A., P. V., M. P. anyagi juttatásban részesült.

Szerzői munkamegosztás: T. L., M. P.: A cikk alapjául szolgáló irodalomkutatás és összefoglaló szövegezés végzése. T. L., B. V., P. V., P. A., Cs. P.: A protokoll elkészítése és szöveges ismertetése. Ny. M., D. T., Cs. P., B. A., M. P.: Szakmai véleményezés. S. B.: A protokoll elkészítése és szöveges ismertetése, PTE-OORI közötti tudományos eredmények kommunikációja és implementációja a protokollba. A cikk végleges változatát valamennyi szerző elolvasta és jóváhagyta.

Érdekeltségek: A szerzőknek nincsenek érdekeltségeik. 


\section{Köszönetnyilvánítás}

Köszönettel tartozunk a PTE KK Idegsebészeti Klinika és Neurorehabilitációs Osztály minden dolgozójának, különösen $d r$. Péley Iván fóorvos úrnak, valamint $d r$. Tasnádi Emese és $d r$. Kovács Noémi szakorvos asszonyoknak, akik minden szakmai kérdésben készséggel segítették munkánkat, így a protokoll összeállításában és a vizsgálat elindulása során is.

\section{Irodalom}

[1] DeVivo MJ. Epidemiology of traumatic spinal cord injury: trends and future implications. Spinal Cord 2012; 50: 365-372.

[2] Ahuja CS, Wilson JR, Nori S, et al. Traumatic spinal cord injury. Nat Rev Dis Primers 2017; 3: 17018.

[3] Chen Y, He Y, DeVivo MJ. Changing demographics and injury profile of new traumatic spinal cord injuries in the United States, 1972-2014. Arch Phys Med Rehabil. 2016; 97: 1610-1619.

[4] van den Berg ME, Castellote JM, Mahillo-Fernandez I, et al. Incidence of spinal cord injury worldwide: a systematic review. Neuroepidemiology 2010; 34: 184-192.

[5] Lenehan B, Street J, Kwon BK, et al. The epidemiology of traumatic spinal cord injury in British Columbia, Canada. Spine (Phila Pa 1976). 2012; 37: 321-329.

[6] Bauman WA, Spungen AM. Metabolic changes in persons after spinal cord injury. Phys Med Rehabil Clin N Am. 2000; 11: 109-140.

[7] Frankel HL, Coll JR, Charlifue SW, et al. Long-term survival in spinal cord injury: a fifty year investigation. Spinal Cord 1998; 36: 266-274.

[8] Myers J, Lee M, Kiratli J. Cardiovascular disease in spinal cord injury: an overview of prevalence, risk, evaluation, and management. Am J Phys Med Rehabil. 2007; 86: 142-152.

[9] North NT. The psychological effects of spinal cord injury: a review. Spinal Cord 1999; 37: 671-679.

[10] No authors listed. Spinal cord injury facts and figures at a glance. J Spinal Cord Med. 2014; 37: 117-118.

[11] Harrop JS, Naroji S, Maltenfort MG, et al. Neurologic improvement after thoracic, thoracolumbar, and lumbar spinal cord ( $\mathrm{CO}^{-}$ nus medullaris) injuries. Spine (Phila Pa 1976). 2011; 36: 21-25.

[12] Khorasanizadeh M, Yousefifard M, Eskian M, et al. Neurological recovery following traumatic spinal cord injury: a systematic review and meta-analysis. J Neurosurg Spine online 2019 Feb 15 Doi: 10.3171/2018.10.SPINE18802. [Epub ahead of print]

[13] Nas K, Yazmalar L, Şah V, et al. Rehabilitation of spinal cord injuries. World J Orthop. 2015; 6: 8-16.

[14] Yarkony GM, Roth EJ, Heinemann AW, et al. Spinal cord injury rehabilitation outcome: the impact of age. J Clin Epidemiol. 1988; 41: 173-177.

[15] Mehrholz J, Pohl M, Platz T, et al. Electromechanical and robotassisted arm training for improving activities of daily living, arm function, and arm muscle strength after stroke. Cochrane Database Syst Rev. 2018; 2018(9): CD006876.

[16] Bertani R, Melegari C, De Cola MC, et al. Effects of robot-assisted upper limb rehabilitation in stroke patients: a systematic review with meta-analysis. Neurol Sci. 2017; 38: 1561-1569.

[17] Mekki M, Delgado AD, Fry A, et al. Robotic rehabilitation and spinal cord injury: a narrative review. Neurotherapeutics 2018; 15: 604-617.

[18] Cheung EY, Ng TK, Yu KK, et al. Robot-assisted training for people with spinal cord injury: a meta-analysis. Arch Phys Med Rehabil. 2017; 98: 2320-2331.e12.

[19] Kim K, Kim YM, Kim EK. Correlation between the activities of daily living of stroke patients in a community setting and their quality of life. J Phys Ther Sci. 2014; 26: 417-419.
[20] Fazekas G, Tavaszi I, Tóth A. New opportunities in neuro-rehabilitation: robot mediated therapy in conditons post central nervous system impairments. [A neurorehabilitáció újabb lehetőségei: terápiás robotok alkalmazása központi idegrendszeri károsodás utáni állapotokban.] Ideggyógy Szle. 2016; 69: 148154. [Hungarian]

[21] Fazekas G. Robotic and other advanced therapies in neuro-rehabilitation: an overview from the beginning to the present and future perspectives. [Robotos és más fejlett technológián alapuló terápiák a neuro-rehabilitációban: áttekintés a kezdetektől napjainkig és kitekintés a közeljövőbe.] Rehabilitáció 2019; 29: 6061. [Hungarian]

[22] Molteni F, Gasperini G, Cannaviello G, et al. Exoskeleton and end-effector robots for upper and lower limbs rehabilitation: Narrative review. PMR 2018; 10(9 Suppl 2): S174-S188.

[23] Zhang X, Yue Z, Wang J. Robotics in lower-limb rehabilitation after stroke. Behav Neurol. 2017; 2017: 3731802.

[24] Kwakkel G, Kollen BJ, Krebs HI. Effects of robot-assisted thera py on upper limb recovery after stroke: a systematic review. Neurorehabil Neural Repair 2008; 2: 111-121.

[25] Miller LE, Zimmermann AK, Herbert WG. Clinical effectiveness and safety of powered exoskeleton-assisted walking in patients with spinal cord injury: systematic review with meta-analysis. Med Devices (Auckl). 2016; 9: 455-466.

[26] Zeilig G, Weingarden H, Zwecker M, et al. Safety and tolerance of the ReWalk ${ }^{\mathrm{TM}}$ exoskeleton suit for ambulation by people with complete spinal cord injury: a pilot study. J Spinal Cord Med. 2012; 35: 96-101.

[27] Esquenazi A, Talaty M, Packel A, et al. The ReWalk powered exoskeleton to restore ambulatory function to individuals with thoracic-level motor-complete spinal cord injury. Am J Phys Med Rehabil. 2012; 91: 911-921.

[28] Juszczak M, Gallo E, Bushnik T. Examining the effects of a powered exoskeleton on quality of life and secondary impairments in people living with spinal cord injury. Top Spinal Cord Inj Rehabil. 2018 ; 24: 336-342.

[29] Baunsgaard CB, Nissen UV, Brust AK, et al. Exoskeleton gait training after spinal cord injury: an exploratory study on secondary health conditions. J Rehabil Med. 2018; 50: 806-813.

[30] Asselin P, Knezevic S, Kornfeld S, et al. Heart rate and oxygen demand of powered exoskeleton-assisted walking in persons with paraplegia. J Rehabil Res Dev. 2015; 52: 147-158.

[31] Akter F, Islam S, Haque $\mathrm{O}$, et al. Barriers for individuals with spinal cord injury during community reintegration: a qualitative study. Int J Phys Med Rehabil. 2019; 7: 513.

[32] Barroso FO, Pascual-Valdunciel A, Torricelli D, et al. Noninvasive modalities used in spinal cord injury rehabilitation. Intech Open 2019 Jan 21. Doi: 10.5772/intechopen.83654.

[33] Murray SA, Farris RJ, Golfarb M, et al. FES Coupled with a powered exoskeleton for cooperative muscle contribution in persons with paraplegia. Conf Proc IEEE Eng Med Biol Soc. 2018; 2018: 2788-2792

[34] Field-Fote EC, Roach KE. Influence of a locomotor training approach on walking speed and distance in people with chronic spinal cord injury: a randomized clinical trial. Phys Ther. 2011; 91: 48-60.

[35] Laczkó J, Mravcsik M, Katona P. Control of cycling limb movements: aspects for rehabilitation. Adv Exp Med Biol. 2016; 957: 273-289.

[36] Li Z, Deng C, Zhao K. Human-cooperative control of a wearable walking exoskeleton for enhancing climbing stair activities. IEEE Transactions on Industrial Electronics 2020; 67: 30863095 .

(Maróti Péter dr., Pécs, Szigeti út 12., 7624 e-mail: peter.maroti@aok.pte.hu)

A cikk a Creative Commons Attribution 4.0 International License (https://creativecommons.org/licenses/by/4.0/) feltételei szerint publikált Open Access közlemény. (SID_1) 